\title{
Corruption and Problem of Public Accountability in Village Governance
}

\author{
Irma Fitriana Ulfah ${ }^{1}$, La Ode Machdani Afala ${ }^{2}$, Fathur Rahman ${ }^{3}$ \\ 1,2,3 Universitas Brawijaya, Indonesia \\ 1. fitriana@ub.ac.id, ${ }^{2}$ macdani@ub.ac.id, ${ }^{3}$ fathur_rahman@ub.ac.id
}

\begin{abstract}
The article intends to explain about corruption and its relation with public accountability in village governance of Semare. The corruption is an extraordinary crime ruining government institution like village and impacting huge risk for villagers. The article was conducted with using qualitative method in collecting the data and borrowing public accountability concept as an approach in analyzing the corruption of Semare Village. As a result, the presence of corruption represents a failure of institution in implementing good governance like accountability. The problem of public accountability in the case of Semare village was rooted not only from problem of institution, but also a strong familial bond replacing formal procedures in village budgeting management.
\end{abstract}

Keywords: Corruption; Village; Public Accountability; Governance

\section{INTRODUCTION}

The article aims to explain relationship between corruption and problem of public accountability in the village governance of Semare. Corruption is a major problem in all government institutions, while public accountability is a basic principle in good governance. The problem of corruption comes into institution due to the lack of public accountability. It can be seen in case of Semare village to address the problem. Semare Village becomes as a site of this research because of some considerations such as; firstly, Semare Village is one of the villages involved in case of corruption in Pasuruan Regency. The trend of corruption in villages of Pasuruan has increased slightly after enacting the latest version of village law. Since 2016, there have been seven cases of corruption revealed in village level of Pasuruan involving many actors of village government. Secondly, according to IDM (Village Development Index) status in 2018, Semare village is still in under-developed (tertinggal) which is located in coastal area of Pasuruan regency.

Since the enacting Law no. 6 of 2014 pertaining village, there has been a dramatic shift in many villages. The law is a proclamation symbolic for village in which village has fully authority to manage their development program and to determine their priority independently (Antlov, 2016; Erani, 2019) [1][2]. If in past the village became an object for development, since 2014 village has declared as subject of development. Following the great shift of law, the central government give huge village budget allocation for development every village. The purpose is to reduce poverty and to develop village resource in order to creating prosperity and independency.

But, the huge village budget allocation that has been transferred had been corrupted by some elites for private interest. In Semare Village, corruption was carried out by village 
secretary, M. Athoillah, in case of village budget misuse (ADD and DD) as much as 87, 227, 000 millions from 2014 to 2015 . The court has been jailed him for 3 years. The corruption of Semare village is one of cases in Indonesia, especially in Pasuruan Regency. The case represents a common problem being faced by all village government in many areas of Indonesia. Corruption in Semare village is actually linked to many problem of governance. One of them is the lack of public accountability.

Village finacial governance requires accountabulity, transparency ( H S Putra, 2017) [3] and participation (Astuti, et all, 2015) [4]. Furthermore, the term of accountability is an essential element in good governance (Boven, 2004) [5]. The effective accountability indicates that people (public) can control the government and gain right information ensuring them to trust of government. However, the presence of corruption has gradually ruined the trust of people to government. In many studies, the problem of public accountability is caused by many factors from inside and outside the institution itself. The major consequence is distrust to institution, otherwise, public trust is shaped by effective public accountability (Finn, 1993) [6].

Corruption is one of the problems ruining the accountability. It occurs because the village government, mostly, has not provided yet enough financial management to prevent corruption practice (Novrizal \& Rodger, 2014; Susan \& Budirahayu, 2018) [7] [8]. The huge village allocation budget transferred by central government is not followed by local regulation as an institutional mechanism to prevent corruption. In similar vein, Nurlina et.al. (2019) [9] said that corruption occurred because of lack public accountability rooted from culture, institution arrangement, and socio-politics. Moreover, As-shidiqqi and Wibisono (2018) explained that corruption in village fund is caused by the lack of accountability and the lack of supervision [10]. Those contribute to the problem of public accountability in village level. According to them, the absence of institutional arrangement for preventing corruption is the main problem for good governance.

Furthermore, the presence of elite capture monopolizing the all process of village government program is one of factors causing corruption (Lucas, 2016) [11]. Since the village has earned the huge village allocation, there has been the emergence of new local elites trying to hijack the process of village development. Moreover, political contestation has contributed in pseudo accountability in which accountability is a result of compromise of many political actors (Basuki et. al., 2018) [12]. In different perspective, according to Dowdle (2017) the problem of public accountability is rooted from different history, experience, and concern (sense) [13]. Of course, the problem of corruption in the level of village can be minimized by enhancing accountability (Woodhouse, 2002; Klitgaard, 2000) [14] [15]. All those problems, of course, have potentially contribution for practice of corruption.

Nowadays, corruption is a critical issues in Indonesia faced by many village governments. Even there have been many studies discussing about corruption and problem of accountability in government institution, both relationships are still vague, particularly in village government related to village fund management. Thus, the study aims to address about it.

\section{RESEARCH METHOD}

This study was analyzed by using qualitative method in which the data collection was conducted by interview to village government officials, villages and local government officials, while observation was conducted through going to field in Semare Village. The documents collected were village government document such as APBDes, RKPDes and court decision documents. The data is analysed in purpose to explain problem of public accountability resulted for corruption in village governance. 


\section{RESULTS AND DISCUSSION}

\subsection{Familial Relation in Village Government}

The village administration is carried out by the village head and is assisted by the village administration. In accordance with the Village Law No. 6 of 2014 that the village apparatus consists of the village secretariat, regional implementers and technical implementers. The village apparatus in Semare Village consist of staff, technical implementers, and regional elements. The village head is a milestone in the administration of the village administration and has the authority to appoint and dismiss village officials. It is this authority that makes the village head able to revamp his village apparatus.

The Head of Semare Village H Yajid served for 2 periods, the first period was 2010-2016 and was re-elected in 2016-2022. The change in the Semare Village during the leadership of $\mathrm{H}$ Yajid occurred in 2012 that placed relatives, friends and trusted people in the village government circle.

One of the changes in the village apparatus that was carried out by the Head of H Yajid Village was the stipulation of M Atok Illah as Sub Head of Semare Village Government (KAUR) based on Semare Village Head Decree Number: 141.3/15/424.16.2021 on July 23, 2012 having double position as a temporary official of village secretary of Semare, Kraton Subdistrict, Pasuruan Regency based on Task Letter Number: 141/05/424.216. 21/2014 dated March 10, 2014. One of the decisions was based on the family relationship between the village head and M Atok Illah. Family relationship between the two of them as uncle and niece. In addition to the familial relationship between the village head and the Head of Government, the family relationship was also established between the village treasurer and the technical implementer of irrigation, namely between Mahdi and H Hamim. Hajj Musafak is the older brother of Hajj Yajid. Haji Hafid is the older brother of Haji Hamim and also the father of Mahdi.

In addition to the authority to appoint and dismiss village officials, the Village Head also has the authority as the Holder of Financial Management Authority (PPKD) in accordance with Permendagri (ministry rule) No. 20 of 2018. PPKD consists of village secretaries, Kaur and Kasi, and Kaur Finance. The village secretary is the coordinator of the PPKD, while the Kaur and Kasi have the task of carrying out the activity budget.

The corruption occurred in Semare Village was not like that mandated by the Minister of Home Affairs. Head of Village H Yajid ordered and gave full mandate to the Village Secretary, M Atok Illah, to carry out village financial management. The village head involved more the Sub Head of village Government or temporary official of village secretary compared to the Head of village treasurer. This opened up the chance of how corrupt practices can occur in Semare Village.

The merit system in the management of the village government was not working because the institutional management of the village head was based more on personal trusts shaped in family relations. The formal authority in Semare Village was eventually replaced by family trust so that the authority of the village apparatus did not work in accordance with applicable regulations.

Disbursement of ADD Semare Village had been carried out in accordance with Government Regulation (PP) No. 43 of 2014 namely by the village head and village treasurer. However, after the disbursement of ADD from 2014 to 2015 and DD in 2015 it was then submitted to M. Atok Illah as village secretary. The Head of Semare Village had trusted M Atok Illah as the temporary official of Semare village secretary to manage the budget (Surabaya District Court Data, 2019). 
The village secretary, M Atok Illah, in accordance with his duties, was one of which was to control the implementation of activities that had been set out in the Village Budget but were not carried out properly. This is evident that the Semare Village development planning funded by $\mathrm{ADD}$ and $\mathrm{DD}$ is not in accordance with its implementation. This means that the village secretary cannot carry out his duties. So the lack of accountability of the village secretary led to corrupt practices in Semare Village. Evidence of a mismatch between planning and implementation can be seen in the following table:

\begin{tabular}{|c|c|c|}
\hline $\begin{array}{l}\text { Village Budget Allocation } \\
\text { (ADD) }\end{array}$ & $\begin{array}{l}\text { The Total of Village } \\
\text { Budget Allocation in } \\
\text { Development Plan }\end{array}$ & $\begin{array}{l}\text { The Total of Budget } \\
\text { Manipulation }\end{array}$ \\
\hline Stage I in year of 2014 & $37,240,000$ & $5,985.000$ \\
\hline Stage II in year of 2014 & $40,690,000$ & $1,750,000$ \\
\hline Stage I in year of 2015 & $46,425.000$ & $12,750,000$ \\
\hline
\end{tabular}

Source: Putusan Perkara No. 244/Pid.Sus/TPK/2017/PN Sby

Another task of the village secretary is to compile reports and accountability for the implementation of the village budget. Reports made by M Atok Illah were done by making village budget report which contained a description of the planned activities that had been carried out by submitting supporting data in the form of memorandum of purchase of goods and fictitious receipts.

M Atok Illah ordered Mahdi and Jainul as village treasurers to type and sign receipts as if there were activities in Semare Village using the 2014 Village Fund Allocation and the 2015 Village Fund (Surabaya District Court, 2019). In addition, this receipt was also signed by the village head in the budget report. This shows that the accountability of each actor is weak both by the Village Chief or temporary Village Secretary, the village treasurer, and also the village head. This is because the three of them were actually involved in the manipulation of village budget report preparation.

\subsection{Asymmetrical Relation Between Village Head and BPD}

In periode of 2010-2016 the BPD in Semare Village was chaired by Supriyadi. Its members consisted of Isrok Muhammad Faikul Rouf, Hisbulloh, and Mahfud Maldini. BPD is an institution in the village whose position is equal to the village head. In the state administration, the BPD is a balancing authority of the village head's authority whose job is to carry out the oversight function of the village administration. However, in practice the function of this BPD was not going well. BPD was weak in overseeing village administration. This was because the task as a BPD was a part-time job, so that BPD members did not perform optimally. As stated by Dony S Prosecutor's Office, he said that;

"The BPD in Semare Village is not working as it should, they should exercise strict supervision of every use of village funds. In fact, I see that this BPD is only a stamp officer if needed by the village secretary (Interview with Dono, Pasuruan District Attorney, 2019).

The weakness of the BPD oversight function in the administration of government and village budget management was because the BPD only carried out this function as a formality that was merely giving approval regarding the SPJ report. This is like acknowledgment from BPD, he said that: 
"We as BPD are less strict about monitoring the use of Village Funds. My signature as chairman was also falsified by M Atok illah, that was the signature related to the 2015 Minutes of BPD Decision Meeting (Interview with Supriyadi, BPD Semare, 2019)

Aside from the BPD not being able to carry out its supervisory functions properly, the performance of the BPD was also considered to be low, as stated by the Acting Secretary of Semare Village, he said that;

"To be honest, the role of BPD in Semare Village is like there is no performance" (Interview with Lukman, 2019). The same was conveyed by the public that "the performance is not clear, bro, the election election here is just a formality of all BPD people who have been appointed directly from the head of his village, so the people who support it are all village heads." (Interview with Maulidyah, 2019).

Based on the interview, it is clear that the role of the BPD as the supervisor of the village government was not working and this was caused by BPD members who incidentally were supporters of the village head. BPD was not able to be a balancer for the village head. Even though there was a BPD in the village government structure so that there was no power domination. One of the functions of BPD was to supervise the implementation of village government. But what happened in Semare Village BPD could not carry out its functions. BPD received a report on village administration every year from the village head. But, the report had been manipulated by village secretary.

\section{3 Pseudo Deliberation}

The highest forum in the administration of village governance is village deliberations (Musrebangdes). Village Deliberation is a public forum that is involved by BPD, the village government, and the village community related to essential matters. One of those is related to budget planning. In accordance with article 73 of the Village Law concerning the Draft Budget for Village Revenue and Expenditure, it is submitted by the Village Head and discussed with the Village Consultative Body. This explains the role of the BPD to involve in deliberations in determining village budget planning.

The drafting of budget planning in Semare Village was only a formality and was only attended by trusted people from the village head. Semare Village BPD in 2014-2015 was not involved in the preparation of the Semare Village APBDes (village budgeting planning). In an interview with Supriyadi, Chairman of the Semare Village BPD, he said that

"For the discussion of the RPJMDes, we as the BPD participated in designing and preparing the Semare Village RPJMDes during H. Yajid's tenure. But for the 2014-2015 $A P B D e s$, we all (BPD members) had never been involved by the village government in the 2014-2015 Semare Village Budget discussion. "

In accordance with the Regulation of the Minister of Villages, Development of Disadvantaged Regions, and Transmigration of the Republic of Indonesia Number 2 of 2015 concerning Guidelines for Rules and Procedures for Making Village Deliberations that the Village Deliberation is held in a participatory, democratic, transparent and accountable manner based on community rights and obligations. The exclusion of BPD in ABPDesa planning in 2014 and 2015 showed that village deliberations conducted in Semare Village were not in accordance with the principles in the rule (Permendes PDT). Accountability from the village head and BPD in the form of village planning, particularly the budget planning become 
unaccountable. It opened the practice of corruption in Semare Village carried out by the village secretary.

In addition, the involvement of village communities in village development planning forums was lso very minimal. The village discussion forums were only attended by trusted people of the village head. However, after this corruption, the community was very pro-active in investigating corruption cases in Semare Village. Now, the community together with the NGO of Gerakan Masyarakat Bawah Indonesia (GMBI) of Pasuruan Raya District actively oversees and investigates corruption cases that occur in Semare Village.

\section{4 Lack of budgeting information in Village}

Based on rule no. 6 of 2014 concerning village, village heads in running their authority, it must be in accordance with the principles in the administration of village governance that regulates accountable, transparent, professional, effective and efficient, clean, and free from collusion, corruption, and nepotism. In this regard, a village head is an actor as well as a representative for accountability in the administration of village government.

The process of transparency and accountability in the administration of government also includes the management of village finances. It was indicated by that there are no information boards or billboards that provide information to the people of Semare Village related to the amount of the village budget and what it is intended for. In other words, the low responsibility of the Semare village government towards the community become a factor contributed to the village financial problems Like the results of an interview with the Secretary of Semare, he said that;

"I think financial information is limited, yes, it is known by anyone in under leadership of $H$ Yajid, whether this is wrong from the head of his village or his secretary who does not want to make public reports (interview with Lukman, 2019).

\section{CONCLUSIONS}

Broadly speaking, the main problem of public accountability of the implementation of village governance in Semare Village had been caused by a mismatch between the duties of the authorities and its practice. First is from the special village apparatus in this case the village secretary with the implementation of this authority. The village secretary is the PPKD coordinator, but in practice the village secretary does all the village financial management. This is due to a personal belief in family relations between the village head and the village secretary. Secondly, BPD as the balancing power of village heads is not optimal. Weak function in organizing village governance. Third, village deliberations are not made as the highest forum in village government management. The budget planning preparation in Semare Village seems to be a formality and is only attended by trusted people from the village head. Fourth, the minimum information about village financial management. At this point, creating good governance is crucial to improving village safety and increasing village community participation so that the scope for corruption can be minimized.

\section{REFERENCES}

[1] H. Antlöv, A. Wetterberg, and L. Dharmawan, "Village Governance, Community Life, and the 2014 Village Law in Indonesia," Bull. Indones. Econ. Stud., vol. 52, no. 2, pp. 161-183, May 2016.

[2] E. Yustika, PROKLAMASI DESA | Store Intrans Publishing. 2019. 
[3] P. Hendi Sandi, "Tata Kelola Pemerintahan Desa Dalam Mewujudkan Good Governance di Desa Kalibelo Kabupaten Kediri,” J. Polit. Muda, vol. 6, no. 2, pp. 110 $119,2017$.

[4] T. P. Astuti and Yulianto, "Good Governance Pengelolaan Keuangan Desa Menyongsong Berlakunya Undang-Undang Nomor .6 Tahun 2014,” Univ. Setia Budi Surakarta., vol. 1, no. 6, pp. 1-14, 2015.

[5] M. Bovens, T. Schillemans, and G. R.E, The Oxford Handbook of Public Accountability. New York: Oxford University Press, 2014.

[6] P. Finn, "Public Trust and Public Accountability," Aust. Q., vol. 65, no. 2, p. 50, 1993.

[7] M. Novrizal and O. Podger, “CORRUPTION_PREVENTION_IN_VILLAGE_FINANCE.pdf | Local Government | Governance." [Online]. Available: https://www.scribd.com/document/414454459/CORRUPTION-PREVENTION-INVILLAGE-FINANCE-pdf. [Accessed: 13-Dec-2019].

[8] N. Susan and T. Budirahayu, "Village government capacity in the implementation of village law no. 6 of 2015 in Indonesia," in Sustainable Future for Human Security: Society, Cities and Governance, Springer Singapore, 2017, pp. 17-27.

[9] N. Nurlinah, H. Haryanto, and E. Musdah, "Problem of Public Accountability in Village Governance in Rural Enrekang, Indonesia," Mimb. J. Sos. dan Pembang., vol. 34, no. 2, pp. 332-340, Dec. 2018.

[10] E. A. Ash-shidiqqi and H. Wibisono, "Corruption and Village: Accountability of Village Fund Management on Preventing Corruption (Problems and Challenges)," J. Indones. Leg. Stud., vol. 3, no. 02, pp. 195-212, Dec. 2018.

[11] A. Lucas, "Elite Capture and Corruption in two Villages in Bengkulu Province, Sumatra," Hum. Ecol., vol. 44, no. 3, pp. 287-300, Jun. 2016.

[12] A. Fitri Basuki, R. D. Wahyunengseh, and K. Setyowati, "Accountability and Democratization of Village Budget: How Village Government in Indonesia Respond to This?," 2018.

[13] M. W. Dowdle, Public accountability: Conceptual, historical and epistemic mappings Regulatory Theory: Foundations and applications. .

[14] A. Woodhouse, "Fighting corruption in the World Bank's Kecamatan Development Program," 2002.

[15] R. Klitgaard, R. Maclean-Abaroa, and H. L. Parris, "Corrupt Cities A Practical Guide to Cure and Prevention," Oakland. 